\title{
Expression and Characterization of Sweet Potato Invertase in Pichia pastoris
}

\author{
Wen-Chin Huang, Ai-Yu Wang, Li-Ting Wang, and Hsien-Yi Sung* \\ Department of Agricultural Chemistry, National Taiwan University, No. 1, Section 4, \\ Roosevelt Road, Taipei, Taiwan
}

\begin{abstract}
An invertase cDNA (Ib/fruct1) was cloned from sweet potato leaves and characterized. The deduced amino acid sequence of the $\mathrm{lb} /$ fruct 1 -encoded protein was closely related to vacuolar invertases and included the WECVD catalytic domain characteristic of them. An expression plasmid containing the coding region of lb/fruct 1 under the control of the alcohol oxidase promoter was used to transform the methylotrophic yeast Pichia pastoris. The biochemical properties for the expressed recombinant enzyme, which was determined to be the acid $\beta$-fructofuranosidase with an acidic pl value (5.1), were similar to those of vacuolar invertases purified from sweet potato. Periodic acid/Schiff staining and Con A-Sepharose gel-binding experiments revealed the recombinant invertase to be a glycoprotein containing glucose and/or mannose residues. Furthermore, the carbohydrate moiety appears to be a key determinant of the enzyme's sucrose hydrolysis activity, substrate affinity, and thermal stability.
\end{abstract}

KEYWORDS: Vacuolar invertase; cDNA; sweet potato (Ipomoea batatas); recombinant invertase; Pichia pastoris; glycoprotein

\section{INTRODUCTION}

In plants, invertase ( $\beta$-D-fructofuranoside fructohydrolase; EC 3.2.1.26) catalyzes the conversion of sucrose to glucose and fructose and is crucially involved in phloem unloading, carbon partitioning, responding to pathogens and wounding, and controlling cell differentiation and development ( $1-6$ and references therein). This enzyme has been purified and characterized from a variety of plants (1,7-9), and on the basis of its solubility properties, $\mathrm{pH}$ optima, subcellular localizations, and isoelectric points, it has been categorized into soluble acid, soluble alkaline, and cell-wall forms. Soluble acid invertase, which exhibits optimal activity in the $\mathrm{pH}$ range of 3.5-5.0 and has an acidic pI value, is thought to function in the vacuoles of plant cells. Alkaline invertase, by contrast, is a cytoplasmic enzyme that exhibits optimal activity in the $\mathrm{pH}$ range of 7.07.8 and has an acidic pI value. In the apoplast, cell-wall invertase, which has an acidic $\mathrm{pH}$ optimum and a basic $\mathrm{pI}$ value, is ionically or covalently bound to the cell walls (1).

The sweet potato Ipomoea batatas $\mathrm{L}$. is a dicotyledonous plant that belongs to the family Convolvulaceae. It is used as a food staple, vegetable, and animal feed, for industrial starch extraction, and for various processed products $(10,11)$. Production of sweet potatoes is affected by several internal and external factors, including net photosynthetic rate, photosynthate partition, storage root sink potential, temperature, moisture level, and pathogens $(11,12)$. To study the role of invertase in the development of the sweet potato, we have purified and

* Corresponding author (telephone/fax +886-2-23634729; e-mail: sunghy@ccms.ntu.edu.tw). characterized several invertase isoforms from the leaves of the sweet potato plant (13). Unfortunately, further investigation of the structure-function relationships for these enzymes has been hampered by low yields of the purified proteins. In this paper, we report the cloning of a cDNA encoding vacuolar invertase from sweet potato leaves. By expression of this cDNA in the methylotrophic yeast Pichia pastoris, the invertase was purified and characterized. To our knowledge, this is the first report of production of plant invertase in milligram quantities in a heterologous system.

\section{MATERIALS AND METHODS}

Materials. Guanidinium thiocyanate, phenol, and agarose were purchased from AMRESCO Inc. (Solon, OH). Taq DNA polymerase and plasmid pGEM-T were from Promega Corporation (Madison, WI). Reverse transcriptase and a 5' RACE system were from Life Technologies (Rockville, MD). $\left[\alpha{ }^{-32} \mathrm{P}\right]-\mathrm{dCTP}$, a Rediprime random prime labeling system, a cDNA Synthesis System Plus Kit, and anti-His 6 antibody were all from Amersham Pharmacia Biotech (Uppsala, Sweden). Lambda ZAP II and Gigapack II Gold packaging extract were from Stratagene (La Jolla, CA). Plasmid pPICZ $\alpha$ B, Pichia pastoris strain GS115, and Pichia EasyComp Kit were from Invitrogen (Groningen, The Netherlands). Ni-NTA agarose was from Qiagen (Valencia, CA). Restriction endonucleases were from Life Technologies or New England BioLabs, Inc. (Beverly, MA). Other chemicals were obtained from Sigma Chemical Co. (St. Louis, MO) or Merck (Darmstadt, Germany).

RNA Isolation. Sweet potato (Ipomoea batatas L. cv Tainong 57) plants were grown in a field in natural light. Young leaves (sink leaves) were cut, immediately frozen in liquid nitrogen, and stored at $-70{ }^{\circ} \mathrm{C}$ 
until required. For experimentation, the frozen samples were ground to a fine powder in liquid nitrogen using a mortar and pestle, after which total RNA was extracted using the method of Chomczynski and Sacchi (14). Poly(A) ${ }^{+}$RNA was isolated from the total RNA by oligo(dT)-cellulose chromatography (15).

Cloning of Invertase cDNA. To prepare a DNA probe for invertase, invertase cDNA was amplified by RT-PCR using a pair of primers designed from the conserved regions of plant-invertase sequences $\left(5^{\prime}\right.$ AAAAACTGGATGAACGATCCTAATGGT-3' and 5' -TCTTCCACCTTGAGCAAAGCTTTCAAC- $3^{\prime}$ ) and poly(A) ${ }^{+}$RNA from young sweet potato leaves as a template. The amplified product, which had the predicted size of $1.4 \mathrm{~kb}$, was gel-purified and cloned into pGEM-T vector. The cloned DNA fragment encoding the expected invertase sequence was confirmed by sequencing. It was then ${ }^{32} \mathrm{P}$-labeled using a Rediprime random prime labeling system and used as a probe for screening a cDNA library.

Poly(A) ${ }^{+}$RNA isolated from young sweet potato leaves was used for cDNA synthesis with a cDNA Synthesis System Plus kit. After the addition of an EcoRI linker and digestion with EcoRI, the cDNA was ligated into Lambda ZAP II and packaged into phages using Gigapack II Gold packaging extract. The unamplified library, containing $1.2 \times$ $10^{5}$ recombinant plaque-forming units, was then screened with the 1.4 $\mathrm{kb}^{32} \mathrm{P}$-labeled probe. The positive plaques were isolated, subjected to in vivo excision, and amplified as phagemids for further analysis. To clone the $5^{\prime}$-end of invertase cDNA, $5^{\prime}$ RACE was performed using a $5^{\prime}$ RACE system with a pair of invertase-specific primers (ISPl, 5'GCTT TCCACTTCTTCAACCGGCCATTG-3', and ISP2, 5'-CCACGCAGTGGTCGGGTCCCTAAAGTC-3'). The major 5' RACE product, a $0.9 \mathrm{~kb}$ fragment, was gel-purified, cloned into pGEM-T vector, and sequenced.

Both DNA strands were sequenced using the dideoxy chaintermination method of Tabor and Richardson (16). The sequences were analyzed using the Wisconsin package, version 10.3 (Accelrys Inc., San Diego, CA).

Construction of the Expression Plasmid and Bacterial Strains. To construct the expression plasmid pSPIT1-Y1, the coding region of Ib $\beta$ fruct 1 cDNA was first amplified by PCR with primers P5', 5'-TCTTCGAATTCACATGGCCGCCAC-3' (nucleotides 9-32), and P3'， 5'-TTCATTCCGCGGCCGCAAGAGATAATG-3' (nucleotides 1980-2006) into which EcoRI and NotI restriction sites had been respectively incorporated by changing the nucleotide sequences as italicized above. The amplified fragment was then digested with EcoRI and NotI and ligated into plasmid pPICZ $\alpha$ B, which had been digested with the same restriction enzymes.

E. coli strains XL1-blue, JM 109, and TOP10F' were used for plasmid propagation. For selection and maintenance of the plasmids, bacterial cultures were typically grown at $37{ }^{\circ} \mathrm{C}$ in vigorously aerated Luria-Bertani medium [1\% (w/v) Bacto-tryptone, 0.5\% (w/v) Bactoyeast extract, and $1 \%(\mathrm{w} / \mathrm{v}) \mathrm{NaCl}, \mathrm{pH} 7.0]$ supplemented with $100 \mu \mathrm{g} /$ $\mathrm{mL}$ zeocin for plasmid pSPIT-Y1 and pPICZ $\alpha \mathrm{B}$ or $100 \mu \mathrm{g} / \mathrm{mL}$ ampicillin for other plasmids.

Expression and Purification of Recombinant Invertase in Yeast. Pichia pastoris strain GS115 was transformed with plasmid pSPIT1Y1 using the Pichia EasyComp kit. The transformed cells were then grown in buffered glycerol-complex medium $[0.1 \mathrm{M}$ potassium phosphate, $\mathrm{pH} 6.0,1 \%(\mathrm{w} / \mathrm{v})$ yeast extract, $2 \%(\mathrm{w} / \mathrm{v})$ peptone, $1.34 \%$ $(\mathrm{w} / \mathrm{v})$ yeast nitrogen base $(\mathrm{YNB}), 4 \times 10^{-5} \%(\mathrm{w} / \mathrm{v})$ biotin, and $1 \%$ (v/v) glycerol] at $30^{\circ} \mathrm{C}$ until the $A_{600}$ value reached 2.0. Culture samples were then centrifuged at $3000 \mathrm{~g}$ for $5 \mathrm{~min}$, after which the growth medium was removed, and the cells were resuspended in the buffered methanol-complex medium [0.1 M potassium phosphate, $\mathrm{pH} 6.0,1 \%$ $(\mathrm{w} / \mathrm{v})$ yeast extract, $2 \%(\mathrm{w} / \mathrm{v})$ peptone, $1.34 \%(\mathrm{w} / \mathrm{v}) \mathrm{YNB}, 4 \times 10^{-5} \%$ $(\mathrm{w} / \mathrm{v})$ biotin, and $0.5 \%(\mathrm{v} / \mathrm{v})$ methanol] and grown at $30{ }^{\circ} \mathrm{C}$ for $72 \mathrm{~h}$. Methanol $(0.5 \%(\mathrm{v} / \mathrm{v})$ of the growth medium) was added to the culture every $24 \mathrm{~h}$.

Purification of the recombinant invertase was carried out at $0-4$ ${ }^{\circ} \mathrm{C}$. The methanol-induced cultures were centrifuged at $6000 \mathrm{~g}$ for 5 min, after which the invertase-containing supernatant was concentrated by ultrafiltration. The concentrated enzyme solution was then loaded onto a Ni-NTA agarose column $(1.6 \mathrm{~cm} \times 5 \mathrm{~cm})$ preequilibrated with buffer A $(50 \mathrm{mM}$ sodium phosphate, $\mathrm{pH} 8.0$, and $300 \mathrm{mM} \mathrm{NaCl})$ containing $5 \mathrm{mM}$ imidazole. The column was then washed with buffer A containing $20 \mathrm{mM}$ imidazole and eluted with buffer A containing $250 \mathrm{mM}$ imidazole. Fractions showing invertase activity were collected and dialyzed against PB buffer $(50 \mathrm{mM}$ sodium phosphate, $\mathrm{pH} 7.0$, and $1 \mathrm{mM} \beta$-mercaptoethanol), and the purified enzyme solution was stored at $-20{ }^{\circ} \mathrm{C}$ until required.

Protein Analytic Methods. Invertase activity was assayed at $\mathrm{pH}$ 5.0 as described by Sung and Huang (17). One unit of invertase was defined as the amount of enzyme that catalyzed the formation of $1 \mu \mathrm{mol}$ of reducing sugar from sucrose in $1 \mathrm{~h}$ at $37^{\circ} \mathrm{C}$. The amount of reducing sugar produced was measured by the method of Somogyi-Nelson (18). The protein concentration was determined using the protein-dye binding method (19), with bovine serum albumin serving as the standard protein. Enzymatic deglycosylation of the recombinant invertase was accomplished by incubating $10 \mu \mathrm{g}$ of the invertase for $6 \mathrm{~h}$ at $37^{\circ} \mathrm{C}$ in PB buffer containing 10 units of $N$-glycosidase F (PNGase F), which cleaves all types of $\mathrm{N}$-glycan chains from glycoproteins unless they carry $\alpha-1,3$-linked core fucose residues (20).

Nondenaturing PAGE and SDS-PAGE were carried out according to the method of Laemmli (21), after which the resolved proteins were stained with Coomassie blue R-250. To stain the glycoproteins, the gels were incubated with $0.7 \%(\mathrm{w} / \mathrm{v})$ periodic acid in $5 \%(\mathrm{v} / \mathrm{v})$ acetic acid solution for $3 \mathrm{~h}, 0.2 \%(\mathrm{w} / \mathrm{v})$ sodium metabisulfite in $5 \%(\mathrm{v} / \mathrm{v})$ acetic acid solution for $3 \mathrm{~h}$, and Schiff's reagent for $18 \mathrm{~h}$, as described by Segrest and Jackson (22).

\section{RESULTS AND DISCUSSION}

Cloning of a cDNA Encoding Vacuolar Invertase from Sweet Potato Leaves. To clone the sweet potato invertase cDNA, a $1.4 \mathrm{~kb}$ screening probe was first synthesized by RTPCR using primers containing conserved sequences of plant invertases. The deduced amino acid sequence of the resultant DNA fragment, which contained the conserved $\beta$-fructosidase motif (NDPNG) and catalytic domain (WECVD), was highly homologous to the coding sequences of acid invertases from other plants (data not shown). By use of this fragment as a probe to screen a sweet-potato-leaf cDNA library, two positively hybridizing clones each containing 1.0 and $1.5 \mathrm{~kb}$ of insert DNA were selected for further analysis.

Analysis of the selected clones revealed that they encoded the same amino acid sequence as the screening probe. Moreover, both sequences contained poly(A) tails but lacked translation initiation sequences and the upstream untranslated regions. The rest of the cDNA sequence was then obtained using the $5^{\prime}$ RACE technique. The complete nucleotide sequence of the cDNA, which we named $\mathrm{Ib} \beta$ fruct1, was $2220 \mathrm{bp}$ in length (GenBank accession number AF017082) and contained an open reading frame encoding 656 amino acid residues, beginning at nucleotide 22 and ending with the termination codon TAA (nucleotides 1990-1992). The deduced amino acid sequence of the Ib $\beta$ fruct 1 encoded protein had, respectively, $69.5 \%, 46.2 \%$, and $27 \%$ identity with the vacuolar (23), cell-wall (24), and neutral (25) invertases from carrot, indicating that the $\mathrm{Ib} \beta$ fruct1-encoded protein was most closely related to vacuolar invertase. Figure 1 shows the alignment of the deduced amino acid sequences derived from $\mathrm{Ib} \beta$ fruct 1 and vacuolar invertase cDNAs from various plants. The presence of the WECVD motif characteristic of plant vacuolar invertases (1) confirms that the $\mathrm{Ib} \beta$ fruct1 gene encodes an acid invertase normally localized in vacuoles.

Production of the Recombinant Invertase in Pichia pastoris. The open reading frame of $\mathrm{Ib} \beta$ fruct 1 was cloned into pPICZ $\alpha$ B expression vector, after which the chimeric plasmid was used to transform $P$. pastoris strain GS115 cells. pPICZ $\alpha$ B contains a methanol-inducible alcohol oxidase (AOX1) promoter for expressing the inserted foreign genes in yeast and provides the expressed products with an $\alpha$-factor secretion signal 


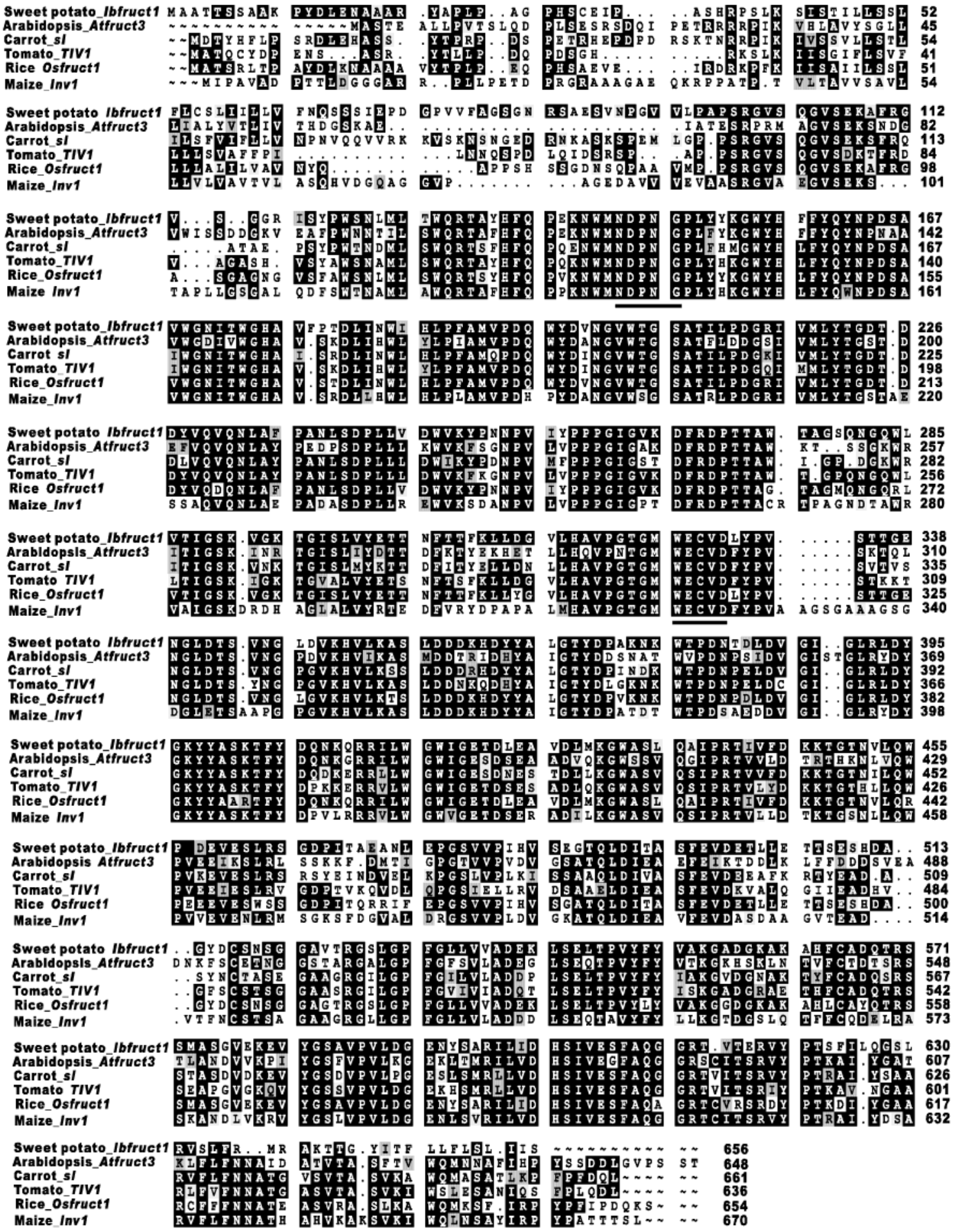

Figure 1. Alignment of the deduced amino acid sequences derived from $\mathrm{lb} \beta$ fruct1 and vacuolar invertase cDNAs from various other plants. The sequences compared were sl from carrot (Daucus carota, CAA53098), TIV1 from tomato (Lycopersicon esculentum, P29000), At $\beta$ fruct3 from Arabidopsis thaliana (X99111), Os $\beta$ fruct1 from rice (Oryza sativa, AAD10239), and Inv1 from maize (Zea mays, P49175). The $\beta$-fructosidase motif (NDPNG) and the catalytic domain (WECVD) of the enzymes are underlined.

in the $\mathrm{N}$ terminus and a His tag in the $\mathrm{C}$ terminus, enabling purification of the expressed proteins directly from the growth medium by affinity chromatography. When the transformed cells were grown for $24 \mathrm{~h}$ at $30{ }^{\circ} \mathrm{C}$ in the presence of methanol, a His-tagged protein with a molecular mass of about $68 \mathrm{kDa}$ was detected in the growth medium by SDS-Western analysis using an anti-His 6 antibody as a probe (Figure 2, panels A and B). Accumulation of acid invertase activity in the growth medium, but not in the intracellular fraction, was also observed (Figure 2C). Because $P$. pastoris strain GS115 is invertase-deficient
(26), the source of the activity could only have been the secreted recombinant protein encoded by $\mathrm{Ib} \beta$ fruct 1 .

Maximal production of the recombinant invertase was obtained after induction for $72 \mathrm{~h}$. Under those conditions, the amount of recombinant invertase secreted into the growth medium reached $4 \mathrm{mg} / \mathrm{L}$ and comprised over $27 \%$ of the total secreted proteins. Purification of the enzyme to apparent homogeneity by Ni-NTA agarose chromatography (Figure 3) produced a 2.5 -fold increase in specific activity and a yield of $70 \%$ (Table 1). 
Table 1. Purification of the Recombinant Invertase from P. pastoris ${ }^{a}$

\begin{tabular}{|c|c|c|c|c|c|}
\hline purification step & $\begin{array}{l}\text { total protein } \\
\quad(\mathrm{mg})\end{array}$ & $\begin{array}{l}\text { total activity } \\
\quad\left(\text { unit }^{b}\right)\end{array}$ & $\begin{array}{l}\text { specific activity } \\
\text { (unit } \mathrm{mg}^{-1} \text { ) }\end{array}$ & $\begin{array}{c}\text { yield } \\
(\%)\end{array}$ & purification \\
\hline $\begin{array}{l}\text { centrifugal supernatant of the culture } \\
\text { ultrafiltration } \\
\text { Ni-NTA agarose }\end{array}$ & $\begin{array}{l}1.34 \\
1.26 \\
0.37\end{array}$ & $\begin{array}{l}0.57 \\
0.52 \\
0.40\end{array}$ & $\begin{array}{l}0.43 \\
0.41 \\
1.08\end{array}$ & $\begin{array}{c}100 \\
91.2 \\
70.1\end{array}$ & $\begin{array}{l}1.0 \text {-fold } \\
1.0 \text {-fold } \\
2.5 \text {-fold }\end{array}$ \\
\hline
\end{tabular}

${ }^{a}$ The data were obtained from the centrifugal supernatant of a $100 \mathrm{~mL}$ culture of methanol-induced $P$. pastoris transformed with the plasmid pSPIT1-Y1. ${ }^{b}$ One unit of invertase was defined as the amount of enzyme that catalyzed the formation of $1 \mu \mathrm{mol}$ of reducing sugar from sucrose in $1 \mathrm{~h}$ at $37^{\circ} \mathrm{C}$.

(A)

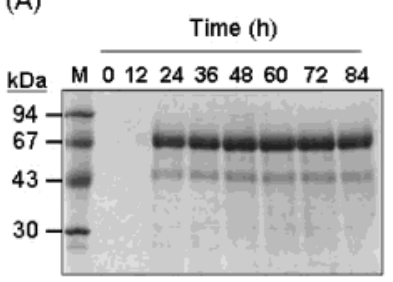

(C)

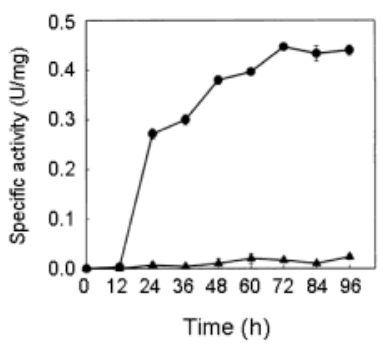

Figure 2. Production of recombinant invertase in $P$. pastoris GS115 cells transformed with plasmid PSPIT1-Y1. Cells were grown in buffered glycerol-complex medium at $30{ }^{\circ} \mathrm{C}$ until $A_{600}$ values reached 2.0 and then in buffered methanol-complex medium at $30^{\circ} \mathrm{C}$ as described in Materials and Methods. Samples collected after various time intervals were centrifuged at $3000 \mathrm{~g}$ for $5 \mathrm{~min}$, after which the proteins in the supernatants were separated by $12.5 \%$ SDS-PAGE $(10 \mu \mathrm{g}$ of protein per lane). The resolved proteins were then stained with Coomassie blue (A) or transferred to a PVDF membrane and immunodetected with anti$\mathrm{His}_{6}$ antibody (B). M indicates molecular mass markers. Proteins in the supernatants of each sample were also assayed for invertase activity at pH $5.0(\mathrm{C})$ : @, P. pastoris transformed with pSPIT1-Y1; $\mathbf{\Delta}, P$. pastoris transformed with $\mathrm{pPICZ} \alpha \mathrm{B}$.

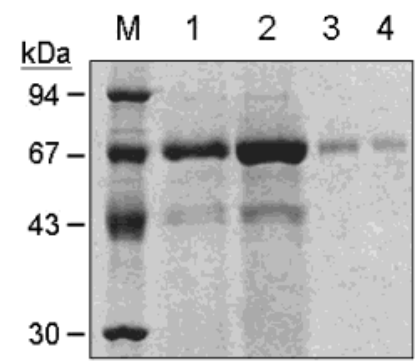

Figure 3. Purification of the recombinant invertase. Protein samples collected at various stages of the purification were separated by $12.5 \%$ SDS-PAGE and then stained with Coomassie blue: $\mathrm{M}$, molecular mass markers; lane 1, the secreted proteins from methanol-induced transformed $P$. pastoris (pSPIT1-Y1); lane 2, the secreted proteins after concentration by ultrafiltration; lanes 3 and 4 , the recombinant invertase purified by Ni-NTA agarose chromatography. The amount of the purified recombinant invertase loaded in lanes 3 and 4 was about 3 and $2 \mu \mathrm{g}$, respectively.

Biochemical Properties of the Recombinant Invertase. The molecular mass of the purified recombinant invertase was 72 and $67.61 \mathrm{kDa}$ as determined by gel filtration chromatography and LC-MS, respectively. The similarity of these values to the

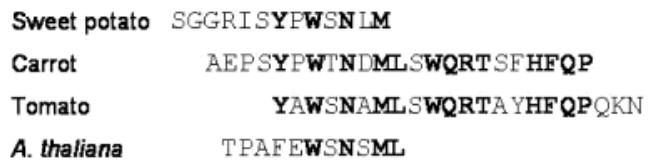

Figure 4. Alignment of the $\mathrm{N}$-terminal sequences of the recombinant sweet potato invertase and vacuolar invertases from carrot (31), tomato (32), and $A$. thaliana (27).

estimate obtained with SDS-PAGE (see above) suggests that the native enzyme is monomeric. The optimal $\mathrm{pH}$ and temperature for the enzyme were 5.0 and $40{ }^{\circ} \mathrm{C}$, and its $\mathrm{pI}$ value was 5.1 (data not shown). The sucrose-hydrolyzing activity of the enzyme could be stabilized with thiol reagents such as $\beta$-mercaptoethanol and dithiothreitol, but when the enzyme solution was dialyzed for $24 \mathrm{~h}$ at $4{ }^{\circ} \mathrm{C}$ against phosphate buffer lacking thiol reagents, $50 \%$ of the original activity was lost. The enzyme hydrolyzed sucrose and raffinose, but not maltose or lactose, indicating it to be a $\beta$-fructofuranosidase. The apparent $K_{\mathrm{m}}$ values for sucrose and raffinose that were determined from Lineweaver-Burk double reciprocal plots were 10.69 and 32.19 $\mathrm{mM}$, respectively.

The biochemical properties detailed above are similar to those of vacuolar invertases purified from sweet potato (13) and various other plants, though the recombinant enzyme possessed a higher $K_{\mathrm{m}}$ value for sucrose than vacuolar invertases from other plants including Arabidopsis ( $5 \mathrm{mM}$ for both INV1 and INV3), strawberry $(3.5 \mathrm{mM})$, barley $(8.1,1.0$, and $1.7 \mathrm{mM}$ for invertase I, IIA, and IIB, respectively), and lily (1, 6.4, and 6.6 $\mathrm{mM}$ for IT1, IT2, and IT3, respectively) $(27-30)$. This may reflect a change in the folded structure of the recombinant protein caused by the $\mathrm{C}$-terminal His tag. In addition, the affinity of the enzyme for sucrose might also be affected by its glycosylation status.

Plant vacuolar invertases are synthesized as preproproteins with a leader sequence containing a signal peptide and an $\mathrm{N}$-terminal extension that are trimmed off during transport and protein maturation (1). The $\mathrm{N}$-terminal sequence of the recombinant invertase determined by Edman degradation was SGGRISYPWSNLM, starting at amino acid residue 114 of the cDNA-derived sequence. This is very similar to the N-terminal sequences of carrot (31), tomato (32), and Arabidopsis (27) vacuolar invertases (Figure 4), suggesting that the leader sequence of the recombinant invertase was trimmed off in $P$. pastoris as in the plant.

Effect of Glycosylation on the Recombinant Invertase. Acid invertases from various plant species have been shown to be glycosylated. Moreover, post-translational glycosylation is also involved in the secretion of heterologously expressed proteins from $P$. pastoris (33), though the glycosylation level and carbohydrate structures on the secreted recombinant proteins vary from protein to protein and may differ from those on the authentic proteins $(34,35)$. As shown in Figure 5, the recombinant invertase secreted from $P$. pastoris is a glycoprotein and can be stained with Schiff's reagent. Although the carbo- 
(A)

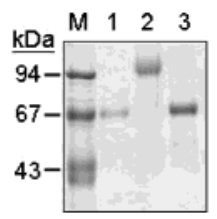

(B)

$\begin{array}{lll}1 & 2 & 3\end{array}$

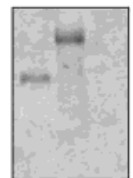

Figure 5. Glycoprotein staining for the recombinant invertase. Purified recombinant invertase was separated on $12.5 \%$ SDS-PAGE, after which the resolved proteins were stained with Coomassie blue $(A)$ or with periodic acid-Schiff stain (B): $M$, molecular mass markers; lane 1, purified recombinant invertase; lane 2, invertase from Candida utilis (positive control); lane 3, bovine serum albumin (negative control).

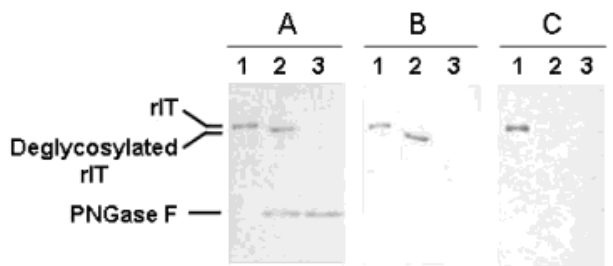

Figure 6. Analysis of the deglycosylated recombinant invertase. Purified recombinant invertase was incubated for $6 \mathrm{~h}$ at $37^{\circ} \mathrm{C}$ in PB buffer with or without PNGase $\mathrm{F}$. The protein mixtures were then separated on $12.5 \%$ SDS-PAGE, after which the resolved proteins were stained with Coomassie blue $(A)$, transferred to a PVDF membrane and immunodetected with a polyclonal antiserum raised against the purified recombinant invertase (B), or stained for glycoproteins with periodic acid-Schiff stain (C). Lane 1, purified recombinant invertase (rIT); lane 2, purified recombinant invertase treated with PNGase F; lane 3, PNGase F.

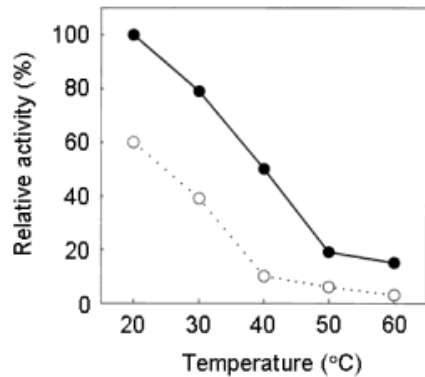

Figure 7. Thermal stability of the recombinant invertase. Purified intact $(0)$ and deglycosylated $(O)$ recombinant invertases were incubated for $30 \mathrm{~min}$ at various temperatures. The residual invertase activity was determined at $\mathrm{pH} 5.0$ and $37{ }^{\circ} \mathrm{C}$. The residual activity of intact enzyme incubated at $20^{\circ} \mathrm{C}$ was designated as $100 \%$.

hydrate structures on the enzyme were not determined, the tight binding of the enzyme to Con A-Sepharose gel indicates that it contains glucose and/or mannose residues (data not shown).

To examine the extent of glycosylation of the recombinant invertase, the enzyme was subjected to deglycosylation with PNGase F, yielding a deglycosylated form of about $63 \mathrm{kDa}$, as estimated by SDS-PAGE (Figure 6). This value was very close to the calculated molecular mass of the deduced amino acid sequence $(62.75 \mathrm{kDa})$. As we described above, the molecular mass of the purified recombinant invertase determined by LCMS was $67.61 \mathrm{kDa}$. Therefore, this protein may contain about $7 \%(\mathrm{w} / \mathrm{w})$ glycans. The optimal $\mathrm{pH}$ and temperature for the enzyme remained unchanged when the glycans were removed; however, the enzyme activity of the deglycosylated protein was only $61 \%$ of the native form. In addition, deglycosylation reduced the affinity of the enzyme for sucrose $\left(K_{\mathrm{m}}=26.91 \mathrm{vs}\right.$ $10.69 \mathrm{mM}$ for the untreated enzyme). The thermal stability of the enzyme was also affected by deglycosylation (Figure 7).
The residual activities of PNGase $\mathrm{F}$ treated enzyme were $60 \%$, $50 \%, 16 \%, 20 \%$, and $10 \%$ of those of intact enzyme after being incubated at $20,30,40,50$, and $60^{\circ} \mathrm{C}$ for $30 \mathrm{~min}$, respectively. Although Faye et al. (36) reported that enzymatic activity and stability are not significantly affected by an enzyme's carbohydrate moiety, the results of the present study show that the carbohydrate moieties of this particular recombinant invertase are crucial for maintaining optimal functionality of the enzyme.

\section{CONCLUSION}

We have isolated and sequenced a full-length $\mathrm{cDNA}$ ( $\mathrm{Ib} \beta$ fruct1) from the leaves of the sweet potato plant. By expression of $\mathrm{Ib} \beta$ fruct 1 cDNA in a yeast system, homogeneous vacuolar invertase was obtained in milligram quantities. We used the purified enzyme to elucidate the role of the carbohydrate moiety on this enzyme. The mechanistic properties, structure-function relationships, and physiological functions of the enzyme will be addressed in future research.

\section{LITERATURE CITED}

(1) Tymowska-Lalanne, Z.; Kreis, M. The plant invertases: physiology, biochemistry and molecular biology. In Advances in Botanical Research; Callow, J. A., Ed.; Academic Press: New York, 1998; Vol. 28, pp 71-117.

(2) Tang, Q. G.; Lüscher, M.; Sturm, A. Antisense repression of vacuolar and cell wall invertase in transgenic carrot alters early plant development and sucrose partitioning. Plant Cell 1999, 11, $177-189$.

(3) Sturm, A. Invertase. Primary structures, functions, and roles in plant development and sucrose partitioning. Plant Physiol. 1999, $121,1-8$

(4) Kim, J.-Y.; Mahé, A.; Brangeon, J.; Prioul, J.-L. A maize vacuolar invertase, IVR2, is induced by water stress. Organ/tissue specificity and diurnal modulation of expression. Plant Physiol. 2002, 124, 71-84.

(5) Rosenkranz, H.; Vogel, R.; Greiner, S.; Rausch, T. In wounded sugar beet (Beta vulgaris L.) tap-root, hexose accumulation correlates with the induction of a vacuolar invertase isoform. $J$. Exp. Bot. 2001, 52, 2381-2385.

(6) Appeldoorn, N. J. G.; Sergeeva, L.; Vreugdenhil, D.; van der Plas, L. H. W.; Visser, R. G. F. In situ analysis of enzymes involved in sucrose to hexose-phosphate conversion during stolon-to-tuber transition of potato. Physiol. Plant. 2002, 115, $303-310$

(7) Isla, M. I.; Vattuone, M. A.; Ordóñez, R. M.; Sampietro, A. R. Invertase activity associated with the walls of Solanum tuberosum tubers. Phytochemistry 1999, 50, 525-534.

(8) Lin, C.-L.; Lin, H.-C.; Wang, A.-Y.; Sung, H.-Y. Purification and characterization of an alkaline invertase from shoots of etiolated rice seedlings. New Phytol. 1999, 142, 427-434.

(9) Hsiao, C.-C.; Fu, R.-H.; Sung, H.-Y. A novel bound form of plant invertase in rice suspension cells. Bot. Bull. Acad. Sin. 2002, $43,115-122$.

(10) Woolfe, J. A. Sweet potato-past and present. In Sweet potato: an untapped food resource; Cambridge University Press: Cambridge, U.K., 1992; pp 15-40.

(11) Jansson, R. K.; Raman, K. V. Sweet potato pest management: a global overview. In Sweet potato pest management: a global perspective; Jansson, R. K., Raman, K. V., Eds; Westview Press: Boulder, CO, 1991; pp 1-12.

(12) Kays, S. J.; Magnuson, C. E.; Fares, Y. Assimilation patterns of carbon in developing sweet potatoes using ${ }^{11} \mathrm{C}$ and ${ }^{14} \mathrm{C}$. In Sweet potato. Proceedings of the first international symposium; Villareal, R. L., Griggs, T. D., Eds; Asian Vegetable Research and Development Center: Tainan, Taiwan, 1982; pp 95-118.

(13) Wang, Y.-L. Studies on soluble acid invertase from sweet potato leaves. Masters Thesis, Graduate Institute of Agricultural Chemistry, National Taiwan University, Taipei, Taiwan, 1995. 
(14) Chomczynski, P.; Sacchi, N. Single-step method of RNA isolation by acid guanidinium thiocyanate-phenol-chloroform extraction. Anal. Biochem. 1987, 162, 156-159.

(15) Sambrook, J.; Fritsch, E. F.; Maniatis, T. Molecular Cloning: A Laboratory Manual, 2nd ed.; Cold Spring Harbor Laboratory Press: Cold Spring Harbor, NY, 1989.

(16) Tabor, S.; Richardson, C. C. DNA sequence analysis with a modified bacteriophage T7 DNA polymerase. Effect of pyrophosphorolysis and metal ions. J. Biol. Chem. 1990, 265, 83228328.

(17) Sung, H.-Y.; Huang, W.-C. Purification and characterization of cell-wall-bound invertase from rice (Oryza sativa) grains. Biotechnol. Appl. Biochem. 1994, 19, 75-83.

(18) Nelson, N. A photometric adaptation of the Somogyi method for the determination of glucose. J. Biol. Chem. 1944, 153, 375380 .

(19) Bradford, M. M. A rapid and sensitive method for the quantitation of microgram quantities of protein utilizing the principle of protein-dye binding. Anal. Biochem. 1976, 72, 248-254.

(20) Tarentino, A. C.; Gomez, C. M.; Plummer, T. H., Jr. Deglycosylation of asparagine-linked glycans by peptide $N$-glycosidase F. Biochemistry 1985, 24, 4665-4671.

(21) Laemmli, U. K. Cleavage of structural proteins during assembly of the head of bacteriophage T4. Nature 1970, 227, 680-685.

(22) Segrest, J. P.; Jackson, R. L. Molecular weight determination of glycoproteins by polyacrylamide gel electrophoresis in sodium dodecyl sulfate. In Methods in Enzymology; Ginsburg, V., Ed.; Academic Press: New York, 1972; Vol. 28, pp 54-63.

(23) Unger, C.; Hardegger, M.; Lienhard, S.; Sturm, A. cDNA cloning of carrot (Daucus carota) soluble acid $\beta$-fructofuranosidases and comparison with the cell wall isoenzyme. Plant Physiol. 1994, 104, 1351-1357.

(24) Ramloch-Lorenz, K.; Knudsen, S.; Sturm, A. Molecular characterization of the gene for carrot cell wall $\beta$-fructosidase. Plant J. 1993, 4, 545-554.

(25) Sturm, A.; Hess, D.; Lee, H. S.; Lienhard, S. Neutral invertase is a novel type of sucrose-cleaving enzyme. Physiol. Plant. 1999, 107, 159-165.

(26) Sreekrishna, K.; Tschopp, J. F.; Fuke, M. Invertase gene (SUC2) of Saccharomyces cerevisiae as a dominant marker for transformation of Pichia pastoris. Gene 1987, 59, 115-125.

(27) Tang, X.; Ruffner, H.-P.; Scholes, J. D.; Rolfe, S. A. Purification and characterisation of soluble invertases from leaves of Arabidopsis thaliana. Planta 1996, 198, 17-23.
(28) Ranwala, A. P.; Suematsu, C.; Masuda, H. Soluble and wallbound invertase in strawberry fruit. Plant Sci. 1992, 84, 59-64.

(29) Obenland, D. M.; Simmen, U.; Boller, T.; Wiemken, A. Purification and characterization of three soluble invertases from barley (Hordeum vulgare L.) leaves. Plant Physiol. 1993, 101, 1331-1339.

(30) Miller, W. B.; Ranwala, A. P. Characterization and localization of three soluble invertase forms from Lilium longiflorum flower buds. Physiol. Plant. 1994, 92, 247-253.

(31) Unger, C.; Hofsteenge, J.; Sturm, A. Purification and characterization of a soluble $\beta$-fructofuranosidase from Daucus carota. Eur. J. Biochem. 1992, 204, 915-921.

(32) Elliott, K. J.; Butler, W. O.; Dickinson, C. D.; Konno, Y.; Vedvick, T. S.; Fitzmaurice, L.; Mirkov, T. E. Isolation and characterization of fruit vacuolar invertase genes from two tomato species and temporal differences in mRNA levels during fruit ripening. Plant Mol. Biol. 1993, 21, 515-524.

(33) Tschopp, J. F.; Sverlow, G.; Kosson, R.; Graig, W.; Grinna, L. High level secretion of glycosylated invertase in the methylotrophic yeast Pichia pastoris. Biotechnology 1987, 5, 13051308.

(34) Trimble, R. B.; Atkinson, P. H.; Tschopp, J. F.; Townsend, R. R.; Maley, K. Structure of oligosaccharides on Saccharomyces SUC2 invertase secreted by the methylotrophic yeast Pichia pastoris. J. Biol. Chem. 1991, 266, 22807-22817.

(35) Montesino, R.; García, R.; Quintero, O.; Cremata, J. A. Variation in $\mathrm{N}$-linked oligosaccharide structures on heterologous proteins secreted by the methylotrophic yeast Pichia pastoris. Protein Expression Purif. 1998, 14, 197-207.

(36) Faye, L.; Berjonneau, C.; Rollin, P. Study on $\beta$-fructosidase from radish seedlings. I. Purification and partial characterization. Plant Sci. Lett. 1981, 22, 77-87.

Received for review October 14, 2002. Revised manuscript received December 29, 2002. Accepted December 30, 2002. This work was supported by grants from the National Science Council, Republic of China.

JF026032I 